\title{
Sovereign Wealth Fund Asset and Liability Management by Rastin Banking Financial Instruments (Rastin Certificates and Rastin Swap Bonds)
}

\author{
Bijan Bidabad \\ B.A., M.Sc., Ph.D., Post-Doc. \\ Professor \\ Economics and Chief Islamic Banking Advisor \\ Bank Melli, Iran \\ E-mail:bijan@bidabad.com
}

\begin{abstract}
Low rate of return of National Development Fund (NDFI) resources and the concern regarding Sovereign Wealth Funds (SWFs) motivations and incentives to distort financing toward those investments and companies that are influenced by different political pressure groups and other types of corruptions are important problems with these funds. We try to propose a different financing procedure by using Rastin Banking mechanism and standards to fulfill both non-usury financial operations and fruitful supervised investments. This goal is achieved through Rastin Profit and Loss Sharing (PLS) system through Rastin Certificates financial instruments. Moreover, the governments operationally construct SWFs to use their surplus resources of the prosperity period in recession and crises years. We also show that Asset and Liability Management (ALM) of SWFs can be done by using Rastin Swap Bonds (RSBs) that are other Rastin Banking financial instruments. The proposed procedures positively improve NDFI regarding corruption reduction, supervision, preventing usury, availability of resources, funds stability, transactable instruments, operational ALM, rate of return, risk of bad loans, outstanding claims and transparency.
\end{abstract}

Keywords: Islamic Finance, financial instrument, Sovereign Wealth Fund, SWF, Rastin Swap Bond, RSB, Finance, Islamic banking, Asset and Liability Management, ALM, National Development Fund, NDFI, Rastin Certificate, Rastin Banking

\section{Introduction}

Assets and Liabilities Management (ALM) consists of technical instruments and methods, which consider both value creation and risk control. A Financial institute applies ALM techniques to increase more benefits by covering himself from risks and minimize losses due to transactions.

Dissimilarities between ALM approaches in Islamic finance, and conventional financing come from differences on usury illegalness and accounting system in Islamic finance in comparison to conventional one. Jurisprudence specifications indicate that time is not the sole effective factor on increasing equity (deposited capital) return, but profit and loss sharing resulted from investment in the real economy sector is the essential base for monetary transactions. These two important factors are considered in Islamic ALM of any financial fund. Non-usury financing requires specific ALM approach to improve efficiency and effectiveness of this type of financing. Islamic finance same as conventional one follows maximizing shareholders assets, but subject to observe Islamic laws and ethics. ${ }^{\mathrm{I}}$

International Working Group of Sovereign Wealth Funds (IWG) defines Sovereign Wealth Fund (SWF) as: special purpose investment funds or arrangements that are established and owned by governments for macroeconomic purposes to hold, manage or administer assets to achieve financial objectives and to employ various investment strategies, including investment in for eign financial assets. ${ }^{2}$ The term SWF is usually used to cover a spectrum of government investment vehicles from central banks and monetary authorities to government-owned enterprises that invest in specific economic sectors. ${ }^{3}$ Several organizations and

${ }^{\mathrm{I}}$ - Bidabad, Bijan, Mahmoud Allahyarifard (2010). Assets and Liabilities Management in Islamic Banking. Paper presentet at the $3^{\text {rd }}$ International Conference on Islamic Banking and Finance. Bidakara, Jakarta, Indonesia, 23 -26 February, 20I0. Proceeding of the Conference: Risk Management, Regulation and Supervision, pp. 396-4I3. http://www.bidabad.com/doc/alm-english.pdf

${ }^{2}$ International Working Group of Sovereign Wealth Funds, (2008) Sovereign Wealth Funds: Generally Accepted Principles and Practices. The "Santiago Principles". http://www.iwg-swf.org/pubs/eng/santiagoprinciples.pdf

3- C. O'brien, T. Mattei, N. Thomas (2012). Sovereign Wealth Funds: Evolving Perceptions and Strategies. International Developments, Vol 
commentators have offered somewhat different definitions that can affect whether certain institutions would be considered as SWF. The appropriate assessment of Sovereign Wealth Fund (SWF)'s ALM requires a deep understanding of assets and liabilities, investments, customers, economic environment and competitive conditions of the capital and monetary sectors. SWF is also defined as an investment vehicle that ${ }^{5}$ :

- Is owned directly by a sovereign government,

- Is managed independently of other state financial institutions,

- Does not predominately have explicit pension obligations,

- Invests in a diverse set of financial asset classes in pursuit of commercial returns

- Has made a significant proportion of its publicly reported investments internationally.

SWFs invest in a broad range of assets such as public equities and fixed income investments assets. Recently SWFs' funds have been directed toward the assets other than stocks, bonds, and cash. The proportion of private equity, real estate, and infrastructure is increasing significantly. ${ }^{6}$

Actually, size of investments, ability to act quickly, autonomy and immediate access to a large amount of capital, fewer public reporting obligations are positive characteristics of SWFs, and enable them to be crucially effective in crises and natural disasters financing and saving bankruptcy of different private and public entities. But, the concern regarding SWFs motivations and incentives to distort financing toward those investments and companies that are influenced by different political pressure groups and other types of corruptions ${ }^{7}$ are very important and have been led to pushing SWFs to increase their transparencies. ${ }^{8}$

To reduce this concern, in this paper, we try to propose a slightly different financing procedure by using Rastin Banking ${ }^{9}$ mechanism and standards to fulfill both non-usury financial operations and fruitful supervised investments. This goal is done through Rastin Profit and Loss Sharing (PLS) system through Rastin Certificates financial instruments.

Moreover, the governments operationally construct SWFs to use their surplus resources of the prosperity period in recession and crises years. In this paper, we also show that ALM of SWFs can be done by using Rastin Swap Bonds (RSBs) that are other Rastin Banking financial instruments.

Rastin Banking is a completely new solution to Islamic banking based on Islamic and ethic teachings with a scientific and technological approach. ${ }^{10}$ Some parts and modules of Rastin Banking have been implemented in Bank Melli Iran. The installed parts of the system are now functioning and have attracted depositors and investors, and since the procedures and instructions are well defined, the bank's staff is performing its procedures easily. The results of the test system are very satisfactory.

\section{Investment Process in National Development Fund of Iran (NDFI)}

National Development Fund of Iran (NDFI) was established to allocate some portions of Iran's oil revenue to durable wealth and productive capital to preserve oil and gas resources for future generations.

NDFI strategies include ${ }^{\mathrm{II}}$ :

\footnotetext{
44, No. 50. December 24.
}

4- Preqin Ltd., (2012), The 20I2 Preqin Sovereign Wealth Fund Review, Preqin Review. https://www.preqin.com/item/20I2-preqinsovereign-wealth-fund-review/I/4985

5- International Working Group of Sovereign Wealth Funds, (October 2008), Sovereign Wealth Funds: Generally Accepted Principles and Practices. "Santiago Principles" http://www.iwg-swf.org/pubs/eng/santiagoprinciples.pdf

6- Preqin Ltd., (2012), The 2012 Preqin Sovereign Wealth Fund Review, Preqin Review. https://www.preqin.com/item/2012-preqinsovereign-wealth-fund-review/I/4985

${ }^{7}$ - L. Cadigan, R. Hadley, E. Robertson, A. (April 2012). FCPA and Other Anti-Corruption Concerns Facing Sovereign Wealth Funds. The Sovereign Wealth Fund Initiative, Sommers, K\&L Gates LLP. The Fletcher School, TUFTS University.

http://fletcher.tufts.edu/SWFI/ /media/Fletcher/Microsites/swfi/pdfs/2012/FCPA\%20KL\%20Final.pdf

${ }^{8}$ - C. O'brien, T. Mattei, N. Thomas (2012). Sovereign Wealth Funds: Evolving Perceptions and Strategies. International Developments, Vol

44, No. 50. December 24. http://fletcher.tufts.edu/SWFI/ /media/Fletcher/Microsites/swfi/pdfs/2012/FCPA\%20KL\%20Final.pdf

${ }^{9}$ The Persian and English documents of Rastin Banking including detailed explanation of this banking method can be accessed through http://www.bidabad.com in full texts.

${ }^{\text {I0 }}$ Bidabad, Bijan, General Characteristics of Rastin Banking, 2013. http://www.bidabad.com/doc/rastin-bank-general-en.pdf

II - National Development Fund of Iran. http://en.ndfi.ir/guidelines.aspx 
- To spotlight outcomes of spatial plans in the country for a regional sustainable and balanced development

- To make plans for reaching the goals of the development plans

- Supporting the private sector to improve economic infrastructure

- Supporting investment opportunities in deprived areas

- Providing financial resources for energy consumption optimization plans

- Participation in foreign monetary and financial markets

- Ensuring the return of NDFI's resources to be preserved for future generations

As it is simply understood from the by-laws ${ }^{12}$ and regulations of NDFI financing procedures and measures, a lot of NDFI's financial operations are usury broadly due to fixing interest rate. ${ }^{13}$ As it was underlined before, Islamic Asset and Liability Management is restricted to use interest-free Islamic financial instruments. This restriction mostly distinguishes Islamic ALM from the conventional one. If NDFI is going to operate usury-free, should adopt different procedures to reach Islamic ALM. This is why we introduce Rastin Banking mechanism to remove usury from NDFI financial operations and increase automatic built-in supervision to reduce corruption concerns. Accordingly, NDFI allocates her resources to investment projects via an agent bank, as is shown ${ }^{14}$ in Figure I.

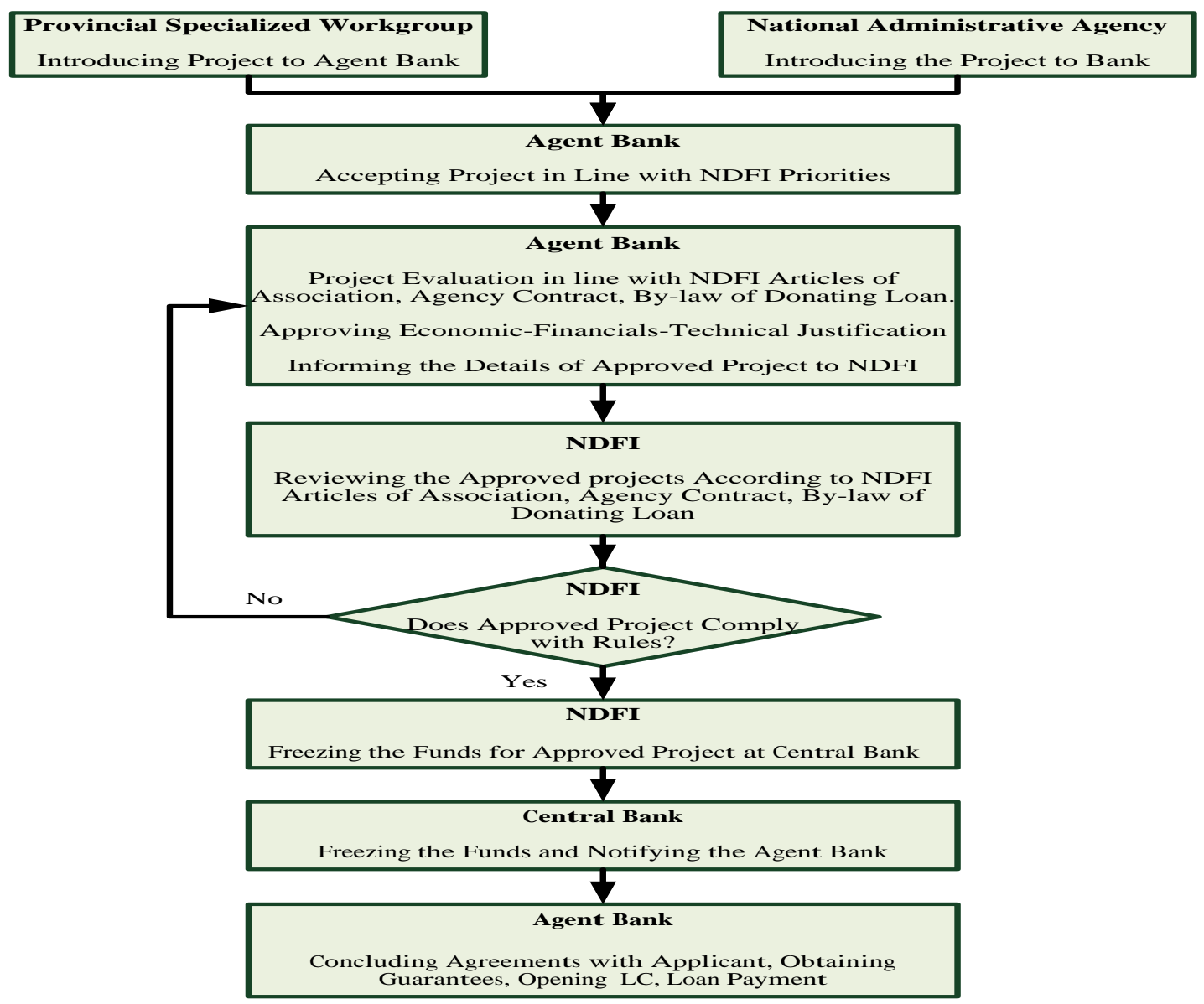

Figure 1. Acceptance, Evaluation, Approval and Allocation of Funds Process in NDFI

Source: National Development Fund of Iran. http://en.ndf.ir/about-us/procedures.aspx

I2- National Development Fund of Iran. http://en.ndf.ir/about-us/by-law.aspx

${ }^{13}$ - National Development Fund of Iran. http://www.ndf.ir/Portals/0/farayand.zip

I4- National Development Fund of Iran. http://en.ndf.ir/about-us/procedures.aspx 


\section{Rastin PLS Base System and its Financial Subsystems}

Rastin PLS Base system ${ }^{15}$ refers to the main process and general regulations of Rastin Profit and Loss Sharing (PLS) Banking system. On request and on behalf of the depositor ${ }^{16}$, the bank ${ }^{17}$ invests his fund in one of Rastin PLS products and instead, gives Rastin Certificate of the selected project ${ }^{18}$ to him and allocates his fund to the selected project of the entrepreneur; and supervises the implementation and execution of the project. In the end, after deducting its own commission, bank divides the profit/loss (if any) among engaged sides (depositors and entrepreneur). The bank is an agent of the depositor, and is responsible for observing his rights (depositor). He must use all his expertise to reach this end. The bank's trustee unit ${ }^{19}$ will supervise the obligations carry out of entrepreneur on behalf of depositor and bank receives a commission for his financial intermediation. In Rastin PLS Base system, Musharakah (Participation) Certificates are used for finite projects ${ }^{20}$, and Pazireh (Subscripted) Certificates are used for infinite projects ${ }^{21}$. These two certificates belong to the category of Rastin Certificates, and activities are done under Rastin Banking regulations. The fixed profit rate is eliminated in Rastin PLS banking, and the return rate is calculated according to the real return of capital in the real economy. Most of the regulations of Rastin PLS Base system are extended to its Financial Subsystems.

To make the bank capable of reaching his goals in a proper way, this system has its own organization, structure, and working process. Major topics in Rastin PLS Base system consist of organizational, professional behavior of assessor ${ }^{22}$ and trustee, project proposal $^{23}$, assessment, guarantees, collaterals and entrepreneur cash contribution (brought), insurance, contract set-out, supervision, entrepreneur ${ }^{24}$, financial transparency, information disclosure, governance, auditing, Rastin Participation Accounting, change of project timing, settlement, bank receipts, transforming Pazireh (Subscripted) Certificates into shares of entrepreneur company, inspection and commodity standard, auxiliary financial tools, unexpected accidents (Force Majeure), arbitration and more...

Rastin PLS Financial Subsystems refer to specific financing methods or services in Rastin PLS Banking. These subsystems work under general regulations of Rastin PLS Base system, and are:

- Joalah Financial Sharing (JFS):25 is a method in which, the bank finances entrepreneur (producer) from depositor's

I5 Bidabad, Bijan, Rastin Profit and Loss Sharing (PLS) Base System. Journal of Islamic Economics, Banking and Finance, pp. 32-57, Vol. 9, No. 4, Oct-Dec 2013.

http://ibtra.com/pdf/journal/v9_n4_article2.pdf

http://www.bidabad.com/doc/pls-base-en.pdf

${ }^{16}$ Depositor is a real or legal person who asks PLS bank to participate his certain amount of fund (cash) in Rastin PLS banking products through direct contact or internet and buys Rastin Certificate of one of the PLS banking products.

${ }^{17}$ In Rastin PLS banking, bank is a unit which allocates resources from depositors to entrepreneur and according to specific contracts the obtained profit or loss is divided between depositor, entrepreneur. By receiving commission (Joalah fee), bank provides capital management services to depositor, and invest his resources according to his choice and in return, delivers Rastin Certificate to him. Bank has to protect depositors' rights by using all his specialized potentialities.

${ }^{18}$ Project is a collection of economic activities with specified and concrete plan with defined cost and term for making profit through Rastin PLS banking offered to PLS bank.

${ }^{19}$ The trustee unit is a unit in Rastin PLS bank for supervision and control of Rastin PLS proposed projects on behalf of bank and regarding good performance of projects in comparison to initial proposal through key indicators and financial reports till final delivery of project.

${ }^{20}$ - Finitude projects are those projects that after completion of construction and by starting utilization period are to be consumed from viewpoints of bank and depositor. Finitude projects are not productive in depositor's viewpoint and do not make value added for depositor, although the depositor in utilization period receives his installments for principal or rent of the project.

${ }^{21}$ - Infinitude projects are those projects that after completion of construction period and starting utilization period are productive in viewpoints of depositor and entrepreneur, and depositor shares in the yield of the project.

${ }_{22}$ Assessment unit is a unit in PLS department of PLS bank which assesses the competence and capabilities of entrepreneur and his proposal.

${ }^{23}$ Proposal is a written document covering a collection of necessary information about the proposed project of entrepreneur and describes analytical justification of the project from economic, technical and financial points of view, with enclosed necessary legal licenses and documents which is submitted to Rastin PLS bank by entrepreneur. After evaluation of bank if be approved, the proposal will be a reference document and can be used against entrepreneur executive operations.

${ }^{24}$ Entrepreneur is a real or legal entity who proposes a project to PLS bank for financing through PLS banking system and executes the project until the end. In addition to have legal, financial, technical and performance capabilities, the entrepreneur should have the other capabilities and facilities/possibilities to carry out the job.

25 Bidabad, Bijan, Joalah Financial Sharing (JFS). Journal of Islamic Economics, Banking and Finance, Volume-I2, No. I, January-March, 2016, pp. 33-48.

http://www.bidabad.com/doc/jfs-paper-en.pdf 
resources or the provided sources by the buyer; by selling Future Certificates (to depositor or buyer) and in the framework of another joalah contract, entrepreneur produces the buyer requested commodity. Future Certificate is used in JFS.

- Mudarabah Financial Sharing (MFS):26 is a kind of mudarabah under Rastin PLS banking in which bank introduces the entrepreneur project proposal in the field of trade or transaction of commodities (commerce) to depositors and by selling them Mudarabah Certificates, finances the entrepreneur (modarib). In MFS Mudarabah and Periodic Mudarabah Certificates are used.

- Installment Financial Sharing (IFS):27 in IFS, installer (moghsit or depositor) will finance a portion of the needed fund of an entrepreneur through the bank for a certain period of time (amortization period). The entrepreneur will pay back his share by installments and will own the total property of the project, and IFS ends. IFS can be carried out through one of the contracts of Ordinary Mughasatah (Installment), Rental Mughasatah (installment) and Musharakah (sharing) Mughasatah (installment); and by application of three related kinds of certificates of Ordinary Mughasatah and Rental Mughasatah Certificates for finite projects and Musharakah Mughasatah Certificate for infinite projects.

- Rent Financial Sharing (RFS):28 entrepreneur temporarily donates the ownership of a part of his productive asset ${ }^{29}$, rental asset ${ }^{30}$, or dead asset ${ }^{31}$ to the depositor who finances him but keeps it as a mortgage. Then pays back the fund received from the yields of the asset proportional to depositor's share to depositor at the end of the contract, or periodically. The original deposit of depositor will be given back to him after the end of the project. The profit of the project will be given to depositor periodically or in a lump. Mortgage Sharing, Periodic Mortgage Sharing, Mortgage Mudarabah (commerce), Periodic Mortgage Mudarabah, Mortgage Muzaraah (cultivating), Periodic Muzaraah, Mortgage Mugharasah (planting), Periodic Mortgage Mugharasah, Mortgage Musaghah (irrigation), Periodic Mortgage Musaghah, Mortgage Istisna (industrial/manufacturing), Periodic Mortgage Istisna and Rental Certificates are used in RFS.

- Bail Financial Sharing (BFS):32 is the application of deposit of depositor by an entrepreneur to produce a defined commodity and delivering the commodity or paying back its value in a future specified time. BFS uses Bail Certificate.

- Rastin Group Funding (RGF): $:^{33}$ is collecting deposits of specific depositors for the specific beneficial project under the regulations of Rastin Banking. In RGF, Rastin certificate is not issued.

- Rastin Personal Security (RPS): $:^{34}$ to create competitive conditions and to increase the efficiency of social security insurance and diminishing antitrust of social security systems and pension funds, private and public pension funds are

http://ibtra.com/pdf/journal/vI2_nI_article2.pdf

26 Bidabad, Bijan, Mudarabah Financial Sharing (MFS). Journal of Islamic Economics, Banking and Finance, 2014.

http://www.bidabad.com/doc/mfs-paper-en.pdf

${ }^{27}$ Bidabad, Bijan, Installment Financial Sharing (IFS): A Financial Subsystem of Rastin PLS Banking. International Journal of Islamic Banking and Finance Research, 3(I), 28-42, 2019.

https://www.cribfb.com/journal/index.php/ijibfr/article/view/267

http://www.bidabad.com/doc/ifs-paper-en.pdf

28 Bidabad, Bijan, Rent Financial Sharing (RFS). Journal of Islamic Economics, Banking and Finance, 2014.

http://www.bidabad.com/doc/rfs-paper-en.pdf

http://ibtra.com/pdf/journal/vIO_n2_article2.pdf

29 "Productive assets" refers to the assets of an operating firm.

30 "Rental assets" refers to those assets, which can be let.

31 "Dead assets" refers to non-operating (suspended) firms or uncultivated lands assets.

32 Bidabad, Bijan, Bail Financial Sharing (BFS): A Financial Subsystem of Rastin PLS Banking. Bank Melli Iran, Tehran, Iran, 2014.

International Journal of Islamic Banking and Finance Research, 3(I), 2I-27, 2019.

https://www.cribfb.com/journal/index.php/ijibfr/article/view/266

http://www.bidabad.com/doc/bfs-paper-en.pdf

${ }^{33}$ Bidabad, Bijan, Rastin Group Funding (RGF): A Financial Subsystem of Rastin Banking. Bank Melli Iran, Tehran, 20I4. International Journal of Islamic Banking and Finance Research, 3(I), 43-48, 2019.

https://www.cribfb.com/journal/index.php/ijibfr/article/view/268

http://www.bidabad.com/doc/rgf-paper-en.pdf

34 Bidabad, Bijan, Rastin Personal Security (RPS). Journal of Islamic Economics, Banking and Finance, JIEBF, Volume - II, Number - 2, April - June 2015, pp. 47-61.

http://ibtra.com/pdf/journal/vII_n2_article3.pdf

http://www.bidabad.com/doc/rps-paper-en.pdf 
established according to Rastin Banking regulations. People and firms can allocate a portion of their obligatory (or optional) insurance premium payments (for himself or his employees) for social security to the funds that operate under Rastin Personal Security (RPS) and enjoy its benefits. Therefore, they will be exempted from obligatory insurance premium payments equal to the payment they have paid to these funds. RPS uses Social Security Certificate, Personal Security Certificate, and Pension Security Certificates.

- $\quad$ Rastin Social Takaful (RST): ${ }^{35}$ benevolent people can deposit their funds at banks for charity purposes, and the bank will be allowed to pay profit (or the principal as well) of deposit to needy people, in the form of a loan or nonreturnable payments (according to the depositor request). RST works under Rastin Banking regulations as "public takaful" (humanistic duty of people to resolve others' needs), or "ziman-e-I'alih" (government duty to provide people's livelihood of the society). In addition, the bank can collect Waqf(devoted) deposits to raise fund. Waqf deposit is a kind of deposit devoted by the depositor (benefactor) to the bank, and the bank will use the yields of this deposit to support needy people in the framework of Rastin Banking regulations. Rastin Social Takaful is applicable by issuing Takaful Certificate and Loan Certificate.

- Sponsor CrowdFunding (SCF):36 is the process of collecting non-returnable funds for a specific protective goal of an entrepreneur through the bank via social networks. In SCF, Rastin certificate is not issued.

- Peer to Peer Loan (PPL): ${ }^{37}$ is the process of collecting funds for loan-financing the entrepreneur through the bank and via social networks. In PPL, Rastin certificate is not issued.

- Rastin Swap Bond (RSB): $:^{38}$ is based upon Mubadalah (swap) contract between Mobadil (swapper) and Motebadil (swapee) in which the durations and substances of swaps are equal for first and second swaps. Motebadil (swapee) issues the bond and owes to Mobadil equal to the nominal value of the bond, and should pay this amount (badal) to Mobadil (swapper) at maturity. The issuer (Motebadil) is obliged to give the mobaadal for the same amount and period as badal to mobadil. He can choose a combination of amount and period that the multiplication of amount by the period of mobaddal be equal to that of badal. At second maturity, mobadil is committed to returning mobaddal to motebadil.

- Rastin Swap Deposit (RSD): $:^{39}$ is a new banking deposit account, which is interest-free and is based on Swap Contract in Rastin Banking. In this depositing by opening the deposit, the depositor is entitled to use an interest-free loan to the amount and duration that his resources have been being deposited and then return the money back to the bank.

- Rastin Swap Card (RSC): $:^{40}$ is a bank card, and has no interest rate and is issued based on the Swap Contract in Rastin Banking. In Rastin Swap Card there are two periods. In the first period, card issuer lends money to the cardholder; and in the second period borrows money from cardholder instead. At the first stage card-issuer credits a certain amount of money for specific time duration to the card of cardholder and requests the cardholder to deposit the same amount for the same period at the end of the cited time duration (first maturity) in the issuer's deposit account.

35 Bidabad, Bijan, Rastin Social Takaful (RST). Journal of Islamic Economics, Banking and Finance, JIEBF, Volume - II, Number - I, January - March 2015, pp.: 13-23.

http://ibtra.com/pdf/journal/vII_nI_articleI.pdf

http://www.bidabad.com/doc/rst-paper-en.pdf

${ }^{36}$ Bidabad, Bijan, Rastin Crowdfunding (RCF): A Financial Subsystem of Rastin Banking. Bank Melli Iran, Tehran, 20I4. International Journal of Islamic Banking and Finance Research, 3(I), 13-20, 2019.

https://www.cribfb.com/journal/index.php/ijibfr/article/view/265

http://www.bidabad.com/doc/rcf-paper-en.pdf

${ }^{37}$ Bidabad, Bijan, Rastin Crowdfunding (RCF): A Financial Subsystem of Rastin Banking. Bank Melli Iran, Tehran, 20I4. International Journal of Islamic Banking and Finance Research, 3(I), 13-20, 2019.

https://www.cribfb.com/journal/index.php/ijibfr/article/view/265

http://www.bidabad.com/doc/rcf-paper-en.pdf

${ }^{38}$ Bidabad, Bijan, Mahmoud Allahyarifard. Usury-Free Bonds and Islamic Central Banking Monetary Instruments. 2010.

http://www.bidabad.com/doc/Islamic-banking-bond-en.pdf

${ }^{39}$ Bidabad, Bijan, Rastin Swap Deposit (RSD): A Financial Account of Rastin Banking. Tehran, 20I5. International Journal of Islamic Banking and Finance Research, 3(2), 17-23, 2019.

https://www.cribfb.com/journal/index.php/ijibfr/article/view/270

http://www.bidabad.com/doc/rsd-paper-en.pdf

https://doi.org/I0.20193/ijibfr.v3i2.270

${ }^{40}$ Bidabad, Bijan, Rastin Swap Card (RSC): A Financial Instrument of Rastin Banking. Tehran, 20I5. International Journal of Islamic Banking and Finance Research, 3(2), 24-3I, 2019.

https://www.cribfb.com/journal/index.php/ijibfr/article/view/27I

http://www.bidabad.com/doc/rsc-paper-en.pdf

http://dx.doi.org/I0.20193/ijibfr.v3i2.27I 
Moreover, Complementary Systems of Rastin Banking that refers to innovations, platforms, and supplementary Rastin Banking methods that facilitate true, ethical, and efficient banking operations will strengthen the operations. They are as follows:

- Rastin Certificate Market (RCM):41 is a web-based settlement system for the transaction of interest-free Rastin Certificates and Rastin Swap Bond in Rastin PLS bank.

- $\quad$ Crowd Funding System (CFS): this system is a web-based system, which collects funds for Sponsor Crowd Funding (SCF) and Peer to Peer Loan (PPL) projects via social networks.

- Operation Control and Monitoring System (OCM): is a computerized web-based system that provides the possibility of online inspection and control of bank personnel activities.

- Mortgage Securitization System (MSS): ${ }^{42}$ this system facilitates people to change their assets into Guarantee Certificates through the bank.

- Collateral Registration System (CRS): is an online web-based integrated system for registering movable and immovable assets.

- Serial Commitments Clearance (SCC):43 provides the necessary arrangements for settlement of obligations of people who are in debt to someone from one hand, while they are creditors to someone else in a chain of debits and credits in a set of people.

- Interbank Withdrawal Protocol (IWP):44 is an interbank agreement that allows the bank to withdraw its claims online from other debtor's accounts o at different banks when the debtor's account at the agent bank is empty.

- Non-usury Scripless Security Settlement System (NSSSS):45 this is an online-integrated web-based settlement system at the central bank for the transaction of Rastin Certificates and Rastin Swap Bonds coordination and supervision.

- Money Laundering Detection System (MLD):46 provides necessary structural and electronic bases to compare tax information and bank information to discover money laundering.

\section{SWF Asset and Liability Management through Rastin Certificates}

Rastin Certificates are a collection of designed certificates in Rastin PLS Banking Base system and its Financial Subsystems. These certificates can be anonymous or named papers, which are transferable and negotiable online through the website of the bank and are issued with a nominal price and for a certain period. The owners of these certificates share the results of the project proportional to nominal price and participation period of the certificate. Bank by issuing and creating market and basket of Rastin Certificates provides various opportunities for the transaction of these papers. Various Rastin Certificates and their

\footnotetext{
${ }^{41}$ Bidabad, Bijan, Rastin Certificate Market (RCM), Complementary System of Rastin Banking, 20I3. International Journal of Islamic Business \& Management, 3(I), 35-43, 2019.

https://www.cribfb.com/journal/index.php/ijibm/article/view/260

http://www.bidabad.com/doc/rastin-bank-rem-en.pdf

${ }^{42}$ Bidabad, Bijan, Mortgage Securitization System (MSS), A Complementary System of Rastin Banking. International Journal of Law and Management (IJLMA), Vol. 59 Issue: 6, pp.778-783, 2017. Emerald Group Publishing Limited

https://doi.org/I0.I I08/IJLMA-05-2016-0045

http://www.bidabad.com/doc/mss-paper-en.pdf

${ }^{43}$ Bidabad, Bijan, Serial Commitments Clearance (SCC) in Rastin Banking. International Journal of Law and Management (IJLMA), Vol. 57, Iss: 6, 2015, pp. 600-609, Emerald Group Publishing Limited.

http://dx.doi.org/I0.1108/IJLMA-02-2015-0007

http://www.bidabad.com/doc/scc-paper-en.pdf

${ }^{44}$ Bidabad, Bijan, Mahmoud Allahyarifard, Interbank Withdrawal Protocol (IWP), Complementary System of Rastin Banking 2013. International Journal of Islamic Business \& Management, 3(I), 30-34, 2019.

https://www.cribfb.com/journal/index.php/ijibm/article/view/259

http://www.bidabad.com/doc/iwp-paper-en.pdf

45 Bidabad, Bijan, Mahmoud Allahyarifard. IT Based Usury Free Financial Innovations. Proceeding of ECDC 2010, 5th International Conference on e-Commerce in Developing Countries: with focus on e-Banking \& e-Insurance. ECDC 2010, I5-I6 September 2010.

http://www.bidabad.com/doc/non-usury-finance-it-en.pdf

${ }^{46}$ Bidabad, Bijan, Money Laundering Detection System (MLD), A Complementary System of Rastin Banking, Journal of Money Laundering Control, Vol. 20 Issue: 4, pp. 354-366, 2017.

https://doi.org/I0.I I08/JMLC-04-2016-0016

http://www.bidabad.com/doc/mld-paper-en.pdf
} 
characteristics according to the kind of participation in the PLS Base system or its Financial Subsystems regarding the type of project and the asset used, will be bound to Rastin Banking regulations.

Regarding the supervisory role of trustee unit of banks over entrepreneurs, these certificates are distinguished from ordinary papers with "certificate" prefix. Being anonymous, transferability, negotiability in the secondary virtual market (Rastin Certificate market), the profitability of their transactions for the bank, pricing according to supply and demand mechanism of Rastin Certificate Market (RCM) ${ }^{47}$, a periodic settlement with the latest certificate owner, are some of the characteristics of these certificates.

By applying Rastin Banking and using Rastin Certificates, NDFI can reach a more safe and efficient resource allocation and investment as depicted by Figure 2 .

As compared by Figure I, in Figure 2, the entrepreneur can also deliver his project proposal to Rastin Agent Bank to finance his project. After the assessment and evaluation of his proposal according to the rules depicted by Figure I, the proposal is ass essed and evaluated according to Rastin Banking standards, which are more subtle and well measured. This step closes many doors of misachievement and malfunctioning and even corruption in using fund resources. As before other national governmental agency and workgroup can introduce their proposals, but subject to observing Rastin Banking rules, regulations, measures, and standards. When the proposal is approved, Rastin Agent Bank signs the contract with entrepreneur and issues corresponding Rastin Certificates according to the specified Rastin Banking product that were cited before in the name of NDFI and delivers these digital certificates to NDFI. NDFI can sell his certificates in Rastin Certificate Market (RCM) at market prices. The certificate holder will owe the principle and benefit of the certificate. He can also transact his certificate in Rastin Certificate Market (RCM) at market price. Bank at the end of the project will settle with certificate holders. According to the rules and regulations of Rastin Banking, ${ }^{48}$ bank supervises the execution of the project, and at the end, account settlement will be done by the bank, and the shares of the entrepreneur, certificate holders, and bank's commission will be paid. This procedure actually has the following major positive effects on NDFI Asset and Liability Management:

- Corruption reduction

- Supervising the execution of the project

- Prevents usury

- NDFI has certificates for his resources that can be transacted

- Asset and Liability Management of NDFI can be done by transacting certificates

- Rate of return of the funds will be increased due to profit and loss sharing

- Risk of bad or delayed loans, outstanding claims, doubtful financing or loans decreases

- Transparency of operations will increase

- By supplying a certificate to Rastin Certificate Market, resources of NDFI will be replaced back by other certificate buyers

- Will stabilize NDFI's funds due to the participation of NDFI in the real project through PLS

\footnotetext{
${ }^{47}$ Rastin Certificate Market (RCM): bank establishes RCM with specific characteristics and capabilities. Different Rastin Certificates and Rastin Swap Bonds can be transacted in this market. Bank activates the information portal about projects and entrepreneurs of Rastin PLS bank through RCM and releases information about Rastin PLS financial projects to public. The system should be capable of online updating the information about available certificates, transactions, settlements, capitalization, transfer or any other activity on Rastin Certificates transactions.

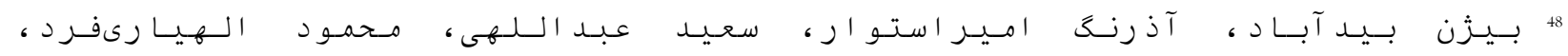

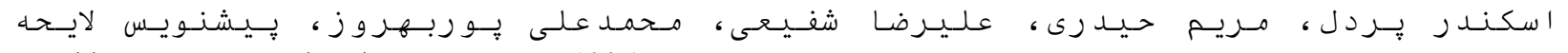

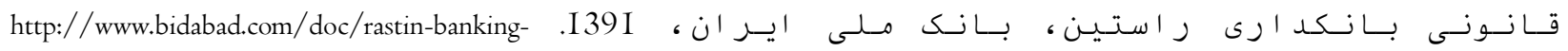
bill.pdf

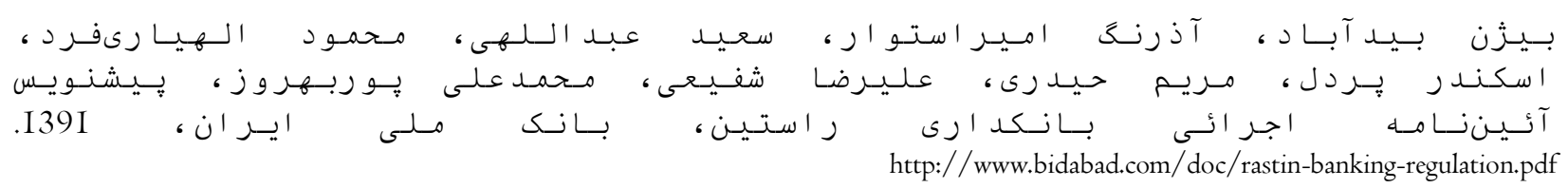




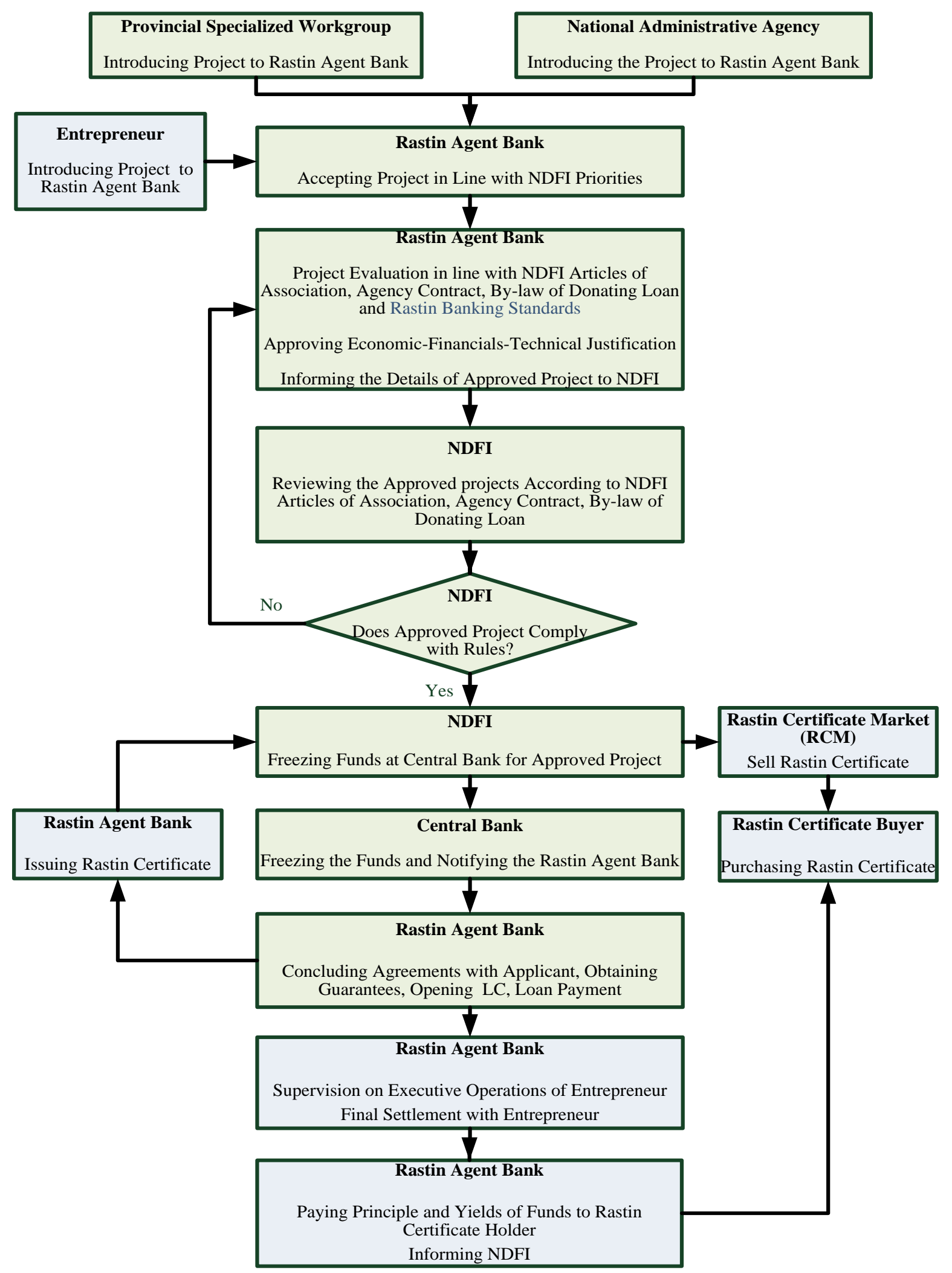

Figure 2. Acceptance, Evaluation, Approval and Allocation of Funds Process in NDFI through Rastin Banking 


\section{Rastin Swap Bonds (RSBs)}

Islamic financial activities based on Islamic faith must stay within the limits of Islamic law in all actions and deeds. To conduct Islamic financial policy, innovative Sharia complied financial instruments are necessary. The prevailed Islamic instruments are controversial among Islamic scholars, and the majority of them believe that such contracts are not Sharia compliant. ${ }^{49}$ Essentially, debt purchase and substance purchase in the non-usury transaction of debt-based financial papers are controversial to be based for innovating Islamic financial instruments. Despite jurisprudents' views that believe transaction of debt-based papers is usury, these transactions are conducted in forms of Murabaha, Partnership, and Ijarah (rent) contracts.

In order to use appropriate financial instrument and policy that are mostly based upon transaction of bonds, we need true Islamic financial innovations, which in addition to complying with Sharia, could be efficient. Rastin Swap Bonds (RSBs) ${ }^{50}$ were defined to remove this shortage. RSBs can be used as Islamic monetary, fiscal and financial instruments in Islamic banking and finance at different levels of central banking, commercial banking, treasury and commercial entities in the conventional banking system as well as Islamic system. ${ }^{51}$ Furthermore, these bonds may be issued in domestic money and foreign currency as well. This instrument is defined in Rastin Banking System.

Rastin Swap Bond is a financial paper that observes the right for the lender to borrow an equal amount to his lending from the borrower. The lender can sell his paper in the market at market price. In this bond, no interest rate is determined, but the market price of the bond is determined at each transaction in the market, and thus, the return of the bond is not fixed and not predetermined. Four types of Rastin Swap Bonds are:

- Central Bank RSB to be issued by the central bank

- Bank RSB to be issued by commercial banks, and money and credit institutions supervised by the central bank

- Treasury RSB to be issued by government treasury

- Commercial RSB to be issued by private or public entities through an agent bank.

The financial structure of Rastin Swap Bonds is substantially different from conventional bonds and bills. In RSBs, while there is no interest, the funds will be offered to the other party in the form of "debt equal to future loan", or "loan equal to future debt" with "time-drawing right". This also differentiates RSBs from conventional bonds, as the latter are interest-bearing securities, whereas RSBs are basically, non-interest-bearing financial investment certificates and with ownership claims. Similar to conventional debt securities, RSBs may be issued for a fixed period. The period variation is due to specific rules.

Each type of RSBs can be transacted in the secondary market (RCM), but the transactions are permitted for different groups of seller and buyers (central bank, commercial banks, treasury, and public) for specific types of RSBs. RSBs pricing will be formed on a base of demand for and supply of money rather than a fixed interest rate for a fixed period. The interest rate of RSBs is zero, but the return is not fixed due to market bonds' prices changes. Thus, interest rate rigidity vanishes, and when the economy goes toward the recession, price (return) of RSBs become lower and reduces the cost of using money resources; and vice versa for the case of going toward prosperity. That is, RSBs has a built-in automatic adjustment mechanism, which stabilizes the economy. In other words, we can say that RSBs market prices will be commensurate to the capital return of the real economy.

Rastin Swap Bonds are issued under certain conditions with a face value. Accordingly, by buying $\$$ A bonds with a maturity of $\mathrm{N}$ months, the buyer will have the right to obtain $\$ \mathrm{~A}$ interest-free loan for a period of $\mathrm{N}$ months from the issuer of bonds. The buyer and seller will agree on fixing combinations of $\$ A$ and $N$ months so that the buyer can choose smaller, equal or larger than one ratios from $\$ \mathrm{~A}$ in proportion with $\mathrm{N}$ months in such a way that the result of the amount of money multiplied by time, be equal to $\mathrm{A} \times \mathrm{N}$. For example, buyer instead of A Dollars, can borrow $\mathrm{A} / 2$ Dollars for $2 \mathrm{~N}$ months at the $\mathrm{N}^{\text {th }}$ month, or $\$ \mathrm{~A} / 3$ for $3 \mathrm{~N}$ months at the $\mathrm{N}^{\mathrm{th}}$ month. Where, in all cases, the result will be equal to $\mathrm{A} \times \mathrm{N}$. That is: $(\mathrm{A} / 2) \times(2 \mathrm{~N})=(\mathrm{A} / 3) \times(3 \mathrm{~N})=\mathrm{A} \times \mathrm{N}$

\footnotetext{
${ }^{49}$ Mansoori, M. T. (2010), Fiqh Regulations on Finance and Business Transaction, Ulil Alba Institute, Pasca Sarjana Universitas Ibn Khaldun, Bogor, Indonesia.

${ }^{50}$ Bidabad, Bijan, Abul Hassan, Ben Ali Mohamed Sami, Mahmoud Allahyarifard. Interest-Free Bonds Financial Innovation, A Monetary Instrument for Economy at Crisis. Journal of Economic Cooperation and Development (JECD). 32, I, 201 I, 55-70.

http://www.sesric.org/jecd/jecd_articles/ARTI0I0220I-2.pdf

${ }^{51}$ - Bidabad, Bijan, Abul Hassan, Mohamed Sami Ben Ali, Mahmoud Allahyarifard (20I I), Interest-Free Bonds and Central Banking Monetary Instruments, International Journal of Economics and Finance, Vol. 3, No.3; August. 
or generally speaking, instead of $\$ A$, we will receive $\$ A / k$ for $k \times N$ months after the $N$ months. The parameter $k$ can be agreed mutually by the parties, or offered by the buyer. This procedure is depicted in Figure 3.

Generally, RSBs have two periods and two maturity dates. The first period is equal to $\mathrm{N}$ months from the selling time to the first maturity, and the second period is from the first maturity date $(\mathrm{N})$ until the payback date of funds $(\mathrm{kN}+\mathrm{N})$ or second maturity date. The first maturity is when the seller of papers is obliged to provide the loan equal to A dollars for $\mathrm{N}$ months, or $\mathrm{A} / \mathrm{k}$ dollars for $\mathrm{kN}$ months to the buyer. Therefore, the first maturity occurs at the end of $\mathrm{N}$ months. The second maturity is the end of the contract when the seller will receive back his funds after $\mathrm{kN}+\mathrm{N}$ months after selling time.

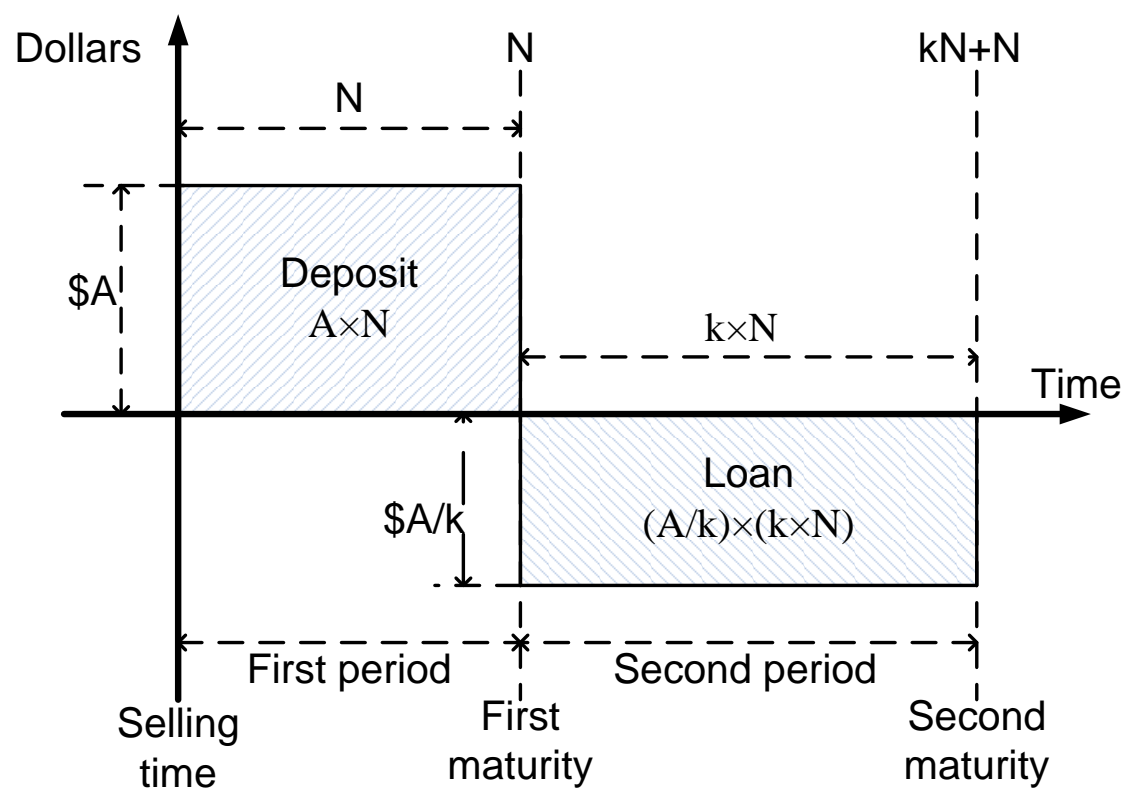

Figure 3. Two-Phases Maturity of Rastin Swap Bonds

The buyers are limited to buy specific types of RSBs.

- If the issuer is treasury (Treasury RSB), then the buyer is the central bank.

- If the issuer is a central bank (Central Bank RSB), then the buyers are government, banks, and those financial institutes who have prudential and legal reserves beside the central bank. Since banks have prudential and legal reserves at the central bank, they will not face loan defaults.

- If the issuer is a commercial bank or financial institute (Bank RSB), then the buyers are a central bank, treasury, other banks, and financial institutes.

- If an agent bank is an issuer (Commercial RSB), then all people, banks, entities, and government can buy the RSB.

- Accordingly, they can transact RSBs in the secondary market.

For the first three types of RSBs, there is no need for extra collaterals due to the existing legal arrangements, but Commercial Rastin Swap Bonds need appropriate mechanism to be arranged to decrease default probability to zero. For this reason, the seller provides a (first) guarantee equal to the face value of bonds at the time of issuance and surrenders it to buyers. At the end of the first period, the buyer will be obliged to surrender the same bank guarantee to the seller of bonds. After returning the funds back from the seller to buyer - at the end of the first period - the first guarantee is canceled. Another (second) guarantee is to be issued again for the second part of borrowing. At the end of the second period -after returning the funds back from the buyer to the seller - the second guarantee will also be canceled. All these operations are done through an agent bank.

All these bonds are issued by the new contract of Mubadalah defined in Rastin Banking. Rastin Swap Bond (RSB) is based upon Mubadalah (swap) contract between Mobadil (swapper) and Motebadil (swapee) in which the durations and substances of 
swaps are equal for first and second swaps. Motebadil (swapee) issues the bond and owes to Mobadil equal to the nominal value of the bond, and should pay this amount (badal) to Mobadil (swapper) at maturity. The issuer (Motebadil) is obliged to give the mobaadal for the same amount and period as badal to mobadil. He can choose a combination of amount and period that the multiplication of amount by the period of mobaddal be equal to that of badal. At second maturity, mobadil is committed to returning mobaddal to motebadil. RSBs are not based upon participation and just indicate swapping of assets and can be transacted in Rastin Rastin Certificate Market.

Similar to RSBs in domestic money, foreign exchange nominated RSBs can also be issued. The only difference is that both loans of Rastin Foreign Exchange Swap Bonds should be in one unique currency; except for the Central Bank Rastin Foreign Exchange Swap Bonds that can be in two different currencies for the first and second periods. Similar to RSBs, the four kinds of Rastin Foreign Exchange Swap Bonds can be issued. The issuers, sellers and buyers of Rastin Foreign Exchange Swap Bonds are as cited before.

In neither cases, especially when one foreign exchange is used for the first period, and another foreign exchange is used in the other period, no skepticism of usury exists.

\section{SWF Asset and Liability Management through Rastin Swap Bonds (RSBs)}

Rastin Swap Bond will serve as an important instrument for resource mobilization and will be a primary vehicle for the development of the Islamic capital market. Sole ${ }^{52}$ argues that expanding the range of financing opportunities by different institutions by developing Sukuk is likely to deepen the financial sector as well as the economy as a whole. Therefore, the effects of issuing RSBs by the central bank, commercial banks, government treasury, and private entities separately will enormously contribute in real sector economy. ${ }^{53}$

To show the applied ALM procedure, suppose that the economy is at the top of a business cycle. The economy is in prosperity, and as a matter of fact, it will go to recession in the next period. At this position, NDFI's resources are high, and the government will be confronted with a fiscal deficit in the next period due to the recession. NDFI start to buy RSB and decrease his cash. The RSB issuer is obliged to return NDFI's fund and lend him an equal amount in the next period that the economy is in recession and government needs some resources to cover her fiscal deficit. At the contrary, in recession or crises period NDFI can issue RSB and finance government fiscal deficit and in next period that the economy grows up to prosperity return his loan back and give equal loan to RSB holders. NDFI can transact RSBs in Rastin Certificate Market to perform Asset and Liability Management.

The monetary effect of Commercial Rastin Swap Bonds is neutral, and will not increase the liquidity, but promotes money resources allocation. This is because these operations will likely to be lagged borrowing from each other. This will result in no changes in liquidity of the economy and is neutral in the sense of monetary effect.

\section{References}

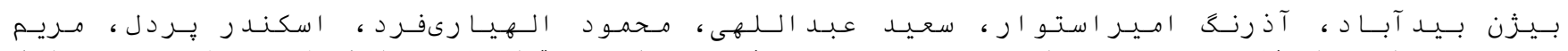

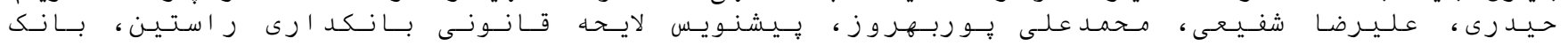

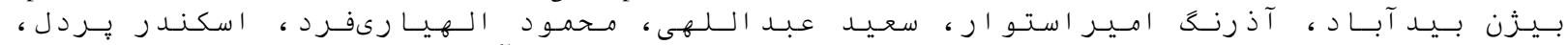

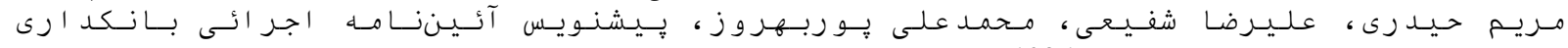

$$
\begin{aligned}
& \text { http://www.bidabad.com/doc/rastin-banking-regulation.pdf }
\end{aligned}
$$

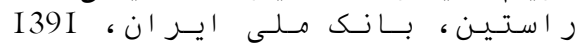

Bidabad, Bijan, New Operational Islamic Banking System, Volume One, Theoretical Foundations, Lap Lambert Academic Publishing, OmniScriptum GmbH \& Co. KG, 20I4, ISBN: 978-3-659-54463-7.

http://www.amazon.com/Rastin-Banking-Operational-Theoretical-

\footnotetext{
52 - Sole, J. (2007). Introducing Islamic banks into conventional banking system. Working Paper No. 07/I75, IMF, Washington, DC.

${ }_{53}^{5 i d a b a d, ~ B i j a n, ~ M a h m o u d ~ A l l a h y a r i f a r d . ~ U s u r y-F r e e ~ B o n d s ~ a n d ~ I s l a m i c ~ C e n t r a l ~ B a n k i n g ~ M o n e t a r y ~ I n s t r u m e n t s . ~} 2010$.

http://www.bidabad.com/doc/Islamic-banking-bond-en.pdf
} 
Foundations/dp/3659544639/ref=sr_I_2?s=books\&ie=UTF8\&qid=I4025635 I8\&sr=I -2

http://pub.npdr.ir/product/rastin-banking/

Bidabad, Bijan, New Operational Islamic Banking System, Volume Two, Applicational Issues, Lap Lambert Academic Publishing, OmniScriptum GmbH \& Co. KG, 20I4, ISBN: 978-3-659-552I0-6.

http://www.amazon.com/Rastin-Banking-II-OperationalApplication/dp/3659552I00/ref=sr_I_I?s=books\&ie=UTF8\&qid=I4046433538sr=I-I

http://pub.npdr.ir/product/rastin-banking-volume-ii/

Bidabad, Bijan, Mahmoud Allahyarifard. IT role in fulfillment of Profit \& Loss Sharing (PLS) mechanism. Proceeding of the $3^{\text {rd }}$ International Islamic Banking and Finance Conference, The Monash University, KL, Malaysia, I6-I7 November, 2005. International Journal of Islamic Banking and Finance Research, 3(2), 44-59, 2019.

https://www.cribfb.com/journal/index.php/ijibfr/article/view/274

http://www.bidabad.com/doc/english-pls-5.pdf

http://www.bidabad.com/doc/pls-it-en.ppt

Bidabad, Bijan; Mahmoud Allahyarifard. Assets and Liabilities Management in Islamic Banking. Proceeding of the $3^{\text {rd }}$ International Conference on Islamic banking and Finance, Risk Management, Regulation and Supervision, Bidakara, Jakarta, Indonesia, 23-26 February, 2010. pp. 396-413. International Journal of Islamic Banking and Finance Research, 3(2), 32-43, 2019. Retrieved from:

https://www.cribfb.com/journal/index.php/ijibfr/article/view/272

http://www.bidabad.com/doc/alm-english.pdf

Bidabad, Bijan, Mahmoud Allahyarifard. IT Based Usury Free Financial Innovations. Proceeding of ECDC 20I0, 5th International Conference on e-Commerce in Developing Countries: with focus on e-Banking \& e-Insurance. ECDC 2010, I5-16 September 2010.

http://www.bidabad.com/doc/non-usury-finance-it-en.pdf

Bidabad, Bijan, Mahmoud Allahyarifard. Usury-Free Bonds and Islamic Central Banking Monetary Instruments. 2010.

http://www.bidabad.com/doc/Islamic-banking-bond-en.pdf

Bidabad, Bijan, Abul Hassan, Ben Ali Mohamed Sami, Mahmoud Allahyarifard. Interest-Free Bonds and Central Banking Monetary Instruments. International Journal of Economics and Finance. Vol. 3, no. 3, Aug 20I I, pp.234-24I.

http://www.ccsenet.org/journal/index.php/ijef/article/download/I I665/8300

Bidabad, Bijan, Mudarebah Financial Sharing (MFS). Journal of Islamic Economics, Banking and Finance, JIEBF, Volume - I0, Number - I, January - April 2014, pp. 56-68.

http://www.bidabad.com/doc/mfs-paper-en.pdf

http://ibtra.com/pdf/journal/vIO_nI_article3.pdf

Bidabad, Bijan, Joalah Financial Sharing (JFS). Journal of Islamic Economics, Banking and Finance, Volume-I2, No. I, January-March, 2016, pp. 33-48.

http://www.bidabad.com/doc/jfs-paper-en.pdf

http://ibtra.com/pdf/journal/vI2_nI_article2.pdf

Bidabad, Bijan, Interest-Free Treasury Bonds (IFTB), Islamic Finance and Legal Clarifications, 20II. International Journal of Islamic Business \& Management, 3(I), 2I-29, 2019.

http://www.bidabad.com/doc/interest-free-t-bond-feqhi-en.pdf

https://www.cribfb.com/journal/index.php/ijibm/article/view/258/353

Bidabad, Bijan, Abul Hassan, Ben Ali Mohamed Sami, Mahmoud Allahyarifard. Interest-Free Bonds Financial Innovation, A Monetary Instrument for Economy at Crisis. Journal of Economic Cooperation and Development (JECD). 32, I, 20II, 55-70.

http://www.sesric.org/jecd/jecd_articles/ARTIOI0220I-2.pdf

Bidabad, Bijan, Installment Financial Sharing (IFS): A Financial Subsystem of Rastin PLS Banking. International Journal of Islamic Banking and Finance Research, 3(I), 28-42, 2019.

https://www.cribfb.com/journal/index.php/ijibfr/article/view/267

http://www.bidabad.com/doc/ifs-paper-en.pdf

Bidabad, Bijan, Rent Financial Sharing (RFS). Journal of Islamic Economics, Banking and Finance, 2014.

http://www.bidabad.com/doc/rfs-paper-en.pdf

http://ibtra.com/pdf/journal/vIO_n2_article2.pdf

Bidabad, Bijan, Rastin Social Takaful (RST). Journal of Islamic Economics, Banking and Finance, JIEBF, Volume - II, Number - I, January - March 2015, pp.: 13-23.

http://ibtra.com/pdf/journal/vII_nI_articleI.pdf

http://www.bidabad.com/doc/rst-paper-en.pdf 
Bidabad, Bijan, Mortgage Securitization System (MSS), A Complementary System of Rastin Banking. International Journal of Law and Management (IJLMA), Vol. 59 Issue: 6, pp.778-783, 2017. Emerald Group Publishing Limited

https://doi.org/IO.I I08/IJLMA-05-2016-0045

http://www.bidabad.com/doc/mss-paper-en.pdf

Bidabad, Bijan, Bail Financial Sharing (BFS): A Financial Subsystem of Rastin PLS Banking. Bank Melli Iran, Tehran, Iran, 20I4. International Journal of Islamic Banking and Finance Research, 3(I), 2I-27, 2019.

https://www.cribfb.com/journal/index.php/ijibfr/article/view/266

http://www.bidabad.com/doc/bfs-paper-en.pdf

Bidabad, Bijan, Rastin Personal Security (RPS). Journal of Islamic Economics, Banking and Finance, JIEBF, Volume - II, Number - 2, April - June 2015, pp. 47-6I.

http://ibtra.com/pdf/journal/vII_n2_article3.pdf

http://www.bidabad.com/doc/rps-paper-en.pdf

Bidabad, Bijan, Joint Stock Company with Variable Capital (JSCVC), International Journal of Law and Management (IJLMA), Emerald Group Publishing Limited, Vol. 56, Iss: 4, pp.302 - 3I0, 2014.

http://dx.doi.org/I0.I I08/IJLMA-09-20I2-003 I

http://www.bidabad.com/doc/vjsc-paper-en.pdf

Bidabad, Bijan, Rastin Profit and Loss Sharing (PLS) Base System. Journal of Islamic Economics, Banking and Finance, pp. 32 57, Vol. 9, No. 4, Oct-Dec 2013.

http://ibtra.com/pdf/journal/v9_n4_article2.pdf

http://www.bidabad.com/doc/pls-base-en.pdf

Bidabad, Bijan, Money Laundering Detection System (MLD), A Complementary System of Rastin Banking, Journal of Money Laundering Control, Vol. 20 Issue: 4, pp. 354-366, 2017.

https://doi.org/I0.I I08/JMLC-04-2016-0016

http://www.bidabad.com/doc/mld-paper-en.pdf

Bidabad, Bijan, General Characteristics of Rastin Banking. Proceeding of the 3rd International Conference on Economics, Political, Law and Fiscal Sciences (EPLS 'I4), World Scientific and Engineering Academy and Society (WSEAS). Transilvania University of Brasov, Brasov, Romania, June 26-28, 2014.

http://www.bidabad.com/doc/rastin-bank-general-en.pdf

http://www.bidabad.com/doc/rastin-bank-general-en.ppt

Bidabad, Bijan, Islamic Monetary Policy, 20I3. International Journal of Islamic Banking and Finance Research, 3(2), I-I6, 2019.

https://www.cribfb.com/journal/index.php/ijibfr/article/view/269 http://www.bidabad.com/doc/islamic-monetary-policy-en.pdf

Bidabad, Bijan, Rastin Certificate Market (RCM), Complementary System of Rastin Banking, 2013. International Journal of Islamic Business \& Management, 3(I), 35-43, 2019.

https://www.cribfb.com/journal/index.php/ijibm/article/view/260

http://www.bidabad.com/doc/rastin-bank-rcm-en.pdf

Bidabad, Bijan, Mahmoud Allahyarifard, Interbank Withdrawal Protocol (IWP), Complementary System of Rastin Banking 2013. International Journal of Islamic Business \& Management, 3(I), 30-34, 2019.

https://www.cribfb.com/journal/index.php/ijibm/article/view/259

http://www.bidabad.com/doc/iwp-paper-en.pdf

Bidabad, Bijan, Change Management of Banking System at National Level by Rastin Banking (Knowledge Management, Empowerment, Prune and Graft, and Apprenticeship), presented at the IOth International Conference on Economics and Management, Islamic Azad University, Rasht, Iran, 2017. Review of Behavioral Aspect in Organizations and Society, 20I9, I(I), I I. Review of Behavioral Aspect in Organizations and Society, I(I), 57-70 .

https://doi.org/I0.32770/rbaos.voli57-70

http://www.bidabad.com/doc/change-banking-en.pdf

http://www.bidabad.com/doc/change-banking-en.pptx

Bidabad, Bijan, Rastin Crowdfunding (RCF): A Financial Subsystem of Rastin Banking. Bank Melli Iran, Tehran, 2014. International Journal of Islamic Banking and Finance Research, 3(I), I3-20, 2019.

https://www.cribfb.com/journal/index.php/ijibfr/article/view/265

http://www.bidabad.com/doc/rcf-paper-en.pdf

Bidabad, Bijan, Rastin Group Funding (RGF): A Financial Subsystem of Rastin Banking. Bank Melli Iran, Tehran, 2014. International Journal of Islamic Banking and Finance Research, 3(I), 43-48, 2019.

https://www.cribfb.com/journal/index.php/ijibfr/article/view/268 
http://www.bidabad.com/doc/rgf-paper-en.pdf

Bidabad, Bijan, Mahshid Sherafati, Bank Information Disclosure, Financial Transparency and Corporate Governance in Rastin Banking, International Journal of Shari'ah and Corporate Governance Research, 2(I), I-I3.

https://www.cribfb.com/journal/index.php/ijscgr/article/view/257

http://www.bidabad.com/doc/shafafiyat-en.pdf

Bidabad, Bijan, Azarang Amirostovar, Mahshid Sherafati, Financial Transparency, Corporate Governance and Information Disclosure of the Entrepreneur's Corporation in Rastin Banking. International Journal of Law and Management (IJLMA), Emerald Group Publishing Limited, Vol:59, Iss:5, pp.636-65I, 2017.

https://doi.org/I0.I 108/IJLMA-0I-2016-0003

Bidabad, Bijan, Mahshid Sherafati, Proposed Regulations for Enforcement of Purports of Binding Banking Documents in Rastin Banking, Tehran, 2015.

http://www.bidabad.com/doc/rastin-bank-ejraye-asnad-en.pdf

Bidabad, Bijan, Saeed Abdollahi, Mahshid Sherafati, Enforcement of the Purports of Binding Banking Documents in Rastin Banking - Part I. International Journal of Law and Management (IJLMA), Emerald Group Publishing Limited, Vol:59, Iss:I, pp. 52-65, 2017.

https://doi.org/I0.II08/IJLMA-07-2015-004I

Bidabad, Bijan, Saeed Abdollahi, Mahshid Sherafati, Enforcement of the Purports of Binding Banking Documents in Rastin Banking - Part II. International Journal of Law and Management (IJLMA), Emerald Group Publishing Limited, Vol:59, Iss:2, pp.I78-19I, 2017.

https://doi.org/I0.I108/IJLMA-I0-2015-0055

Bidabad, Bijan, Serial Commitments Clearance (SCC) in Rastin Banking. International Journal of Law and Management (IJLMA), Vol. 57, Iss: 6, 2015, pp. 600-609, Emerald Group Publishing Limited.

http://dx.doi.org/I0.1108/IJLMA-02-2015-0007

http://www.bidabad.com/doc/scc-paper-en.pdf

Bidabad, Bijan, Rastin Swap Deposit (RSD): A Financial Account of Rastin Banking. Tehran, 2015. International Journal of Islamic Banking and Finance Research, 3(2), 17-23, 2019.

https://www.cribfb.com/journal/index.php/ijibfr/article/view/270

http://www.bidabad.com/doc/rsd-paper-en.pdf

Bidabad, Bijan, Rastin Swap Card (RSC): A Financial Instrument of Rastin Banking. Tehran, 20I5. International Journal of Islamic Banking and Finance Research, 3(2), 24-3I, 2019.

https://www.cribfb.com/journal/index.php/ijibfr/article/view/27I

http://www.bidabad.com/doc/rsc-paper-en.pdf

Bidabad, Bijan, Mahshid Sherafati, Operational Ethical Banking in Rastin Banking (Professional Ethics, Audit, Inspection, Control, Monitoring and Preservation). International Journal of Law and Management (IJLMA), Emerald Group Publishing Limited, Vol: 58, Iss: 4, 2016, pp. 416-443.

http://dx.doi.org/I0.I108/IJLMA-07-2015-0037

http://www.bidabad.com/doc/rastin-ethic-banking-en.pdf

Bidabad, Bijan, General Regulatory Framework in Rastin Profit and Loss Sharing Banking (Part I-Operational Context). Journal of Business and Finance in Emerging Markets, JBFEM, [S.1.], v. I, n. I, p. I I-26, may 20I8. ISSN 25805568.

https://doi.org/I0.32770/jbfem.volI I I-26

http://www.bidabad.com/doc/rastin-regulatory-en-I.pdf

Bidabad, Bijan, General Regulatory Framework in Rastin Profit and Loss Sharing Banking (Part II-Legal Groundwork). Journal of Business and Finance in Emerging Markets, JBFEM, JBFEM, [S.1.], v. I, n. 2, p. 109-126, nov. 2018. ISSN 25805568.

https://doi.org/I0.32770/jbfem.volI I09-I26

http://www.bidabad.com/doc/rastin-regulatory-en-II.pdf

Bidabad, Bijan, General Regulatory Framework in Rastin Profit and Loss Sharing Banking (Part III-Auxiliary Provisions). Journal of Business and Finance in Emerging Markets, JBFEM, May 20I9, Vol 2, No. I, pp. 5I -65. ISSN 25805568.

https://doi.org/I0.32770/jbfem.vol25I-66

http://www.bidabad.com/doc/rastin-regulatory-en-III.pdf

C. O'brien, T. Mattei, N. Thomas (2012). Sovereign Wealth Funds: Evolving Perceptions and Strategies. International Developments, Vol 44, No. 50. December 24.

International Working Group of Sovereign Wealth Funds, (2008), Sovereign Wealth Funds: Generally Accepted Principles 
and Practices. The "Santiago Principles".

http://www.iwg-swf.org/pubs/eng/santiagoprinciples.pdf

L. Cadigan, R. Hadley, E. Robertson, A. (April 20I2). FCPA and Other Anti-Corruption Concerns Facing Sovereign Wealth Funds. The Sovereign Wealth Fund Initiative, Sommers, K\&L Gates LLP. The Fletcher School, TUFTS University. http://fletcher.tufts.edu/SWFI/ /media/Fletcher/Microsites/swfi/pdfs/2012/FCPA\%20KL\%20Final.pdf

Mansoori, M. T. (2010), Fiqh Regulations on Finance and Business Transaction, Ulil Alba Institute, Pasca Sarjana Universitas Ibn Khaldun, Bogor, Indonesia.

National Development Fund of Iran. http://en.ndf.ir/about-us/by-law.aspx

National Development Fund of Iran. http://en.ndf.ir/about-us/procedures.aspx

National Development Fund of Iran. http://en.ndfi.ir/guidelines.aspx

National Development Fund of Iran. http://www.ndf.ir/Portals/0/farayand.zip

Preqin Ltd., (20I2), The 2012 Preqin Sovereign Wealth Fund Review, Preqin Review. https://www.preqin.com/item/2012preqin-sovereign-wealth-fund-review/I/4985

Rastin Banking. http://www.bidabad.com.

Sole, J. (2007). Introducing Islamic banks into conventional banking system. Working Paper No. 07/I75, IMF, Washington, DC.

\section{Copyrights}

Copyright for this article is retained by the author(s), with first publication rights granted to the journal. This is an open-access article distributed under the terms and conditions of the Creative Commons Attribution license (http://creativecommons.org/licenses/by/4.0/). 